\title{
DETERMINATION OF URBAN SPRAWL ON ECOLOGICAL NETWORK USING EDGE ANALYSIS: A CASE STUDY OF USAK (TURKEY)
}

\author{
Nurhan KOCAN $\mathbb{B D}^{*}$ \\ Department of Landscape Architecture, Faculty of Engineering-Architecture and Design, \\ Bartin University, Bartin, Turkey
}

Received 22 May 2020; accepted 12 January 2021

\author{
Highlights \\ City boundary gives clue for future urban sprawl. \\ Urban edge effect is analyzed by using landscape structure indes. \\ Edge analysis can be applicable to other cities to estimate the risks of urban sprawl.
}

\begin{abstract}
The aim of this study is to investigate the effects of the urban development of Usak city onto natural and urban open green spaces around the city during a -fifty- year period between 1954-2004. The data is based on aerial photographs of Usak urban area in 1954, 1971, 1994 and from Ikonos satellite image of 2004. The statistical data and the visual maps created in geographic information system software. This study puts forward the rapid spread of urbanization from 1971 to 1994 and hence, a significant change in landscape mosaic; urban areas increased by $102.9 \%$ between 1954-1971, 226.1\% between 1971-1994 and 99.3\% between 1994-2004. The most crucial change is evident in agricultural and open areas. According to the results of the edge analysis, urban areas, border ecologically valuable natural areas and the highest rate value was found to be in 2004; proving the development of the city towards agricultural areas.
\end{abstract}

Keywords: urban planning, edge effect, ecological planning, open green spaces, Usak City.

\section{Introduction}

Industrialization, one of the most important factors in the development of cities, not only increases job opportunities but also brings about many economic benefits. Therefore, especially during the 1950s, migration to cities in Turkey has rapidly increased leading urban areas to spread onto natural green areas and with the course of industrialization, caused natural green areas to decline continuously.

As the ecological structure is vital for all living things and a change in the eco-system directly or indirectly affects the habitat, determining the changes in natural areas and resources and using these resources in a planned manner is crucial in the future of city development; specifically, in densely populated cites to predict future development trends and to be able to conduct planning decisions.

Upon gaining its provincial status in 1953, the urban development sped up in the city of Usak with its connecting commercial roads between two major cities. Moreover, industrial and business opportunities, convenient living and economic conditions, led to a remarkable urbanization process in the city especially after 1970s. As a result, with the rapid growth of the urban areas as the city started to expand, a significant transformation took place both on the open green spaces surrounding the city and on the open green spaces within the city. Areas in the vicinity of the city, consisting mainly of agricultural areas and open green spaces transformed into residential and industrial areas and some to road uses with low ecological value.

The aim of this study is to reveal the urban growth of Usak over the years by focusing on the spatial and structural transformations in and around the Usak urban area. Transferring the findings of the research to planning practices; it will serve to improve the quality and quantity of urban open green spaces and to protect natural areas with buffer zones. In this respect, the study shows the characteristics that can guide the urban planning, city management and organization studies and it is important as basic data.

${ }^{*}$ Corresponding author. E-mail: nkocan@bartin.edu.tr 


\section{The edge effect}

In ecology, edge refers to a linear area that separates two different habitat types or areas. Edge areas have a direct effect on the communication between living beings and their environment with their dynamic structures.

Therefore, edge areas are sensitive in preserving habitat values of natural areas (Meffe \& Carroll, 1997).

Edge effect stands for the negative impact of the edge or marginal zone between the two habitats of the inner zone that is ecologically significant (Figure 1). Edge parts of natural habitats have fewer sensitive species than inland habitats. Therefore, there is an inverse relationship between the width of the edge of the habitat and the ecologically important areas of habitat (Stevens \& Husband, 1998). The species diversity refers to sensitive or endemic species in that habitat (Esbah, 2001).

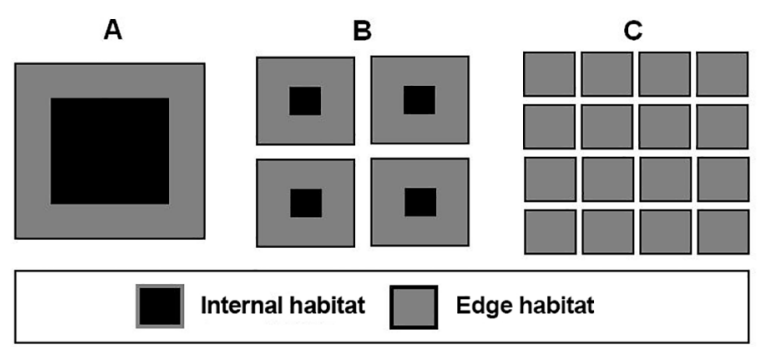

Figure 1. Increased border effect with habitat fragmentation and complete disappearance of internal habitat areas over time (Soule, 1991)

In Figure 1, although the sum of the area is equal in all three cases, the boundary length of the areas is different. As the fragmentation creates new areas within the habitat, it leads to an increase in border length. The inner (core) area, which is the most important center for a habitat, gradually decreases and eventually disappears (Soule, 1991). More fragmented areas losing their internal areas mean a decrease in specific species special to that habitat (Deniz, 2005).

The presence of species in a habitat depends not only on the size and structure of that area, but also on the landscape structure surrounding it (Wegner \& Merriam, 1979; Sounders et al., 1991). As the structural differences between the types of land use and surrounding habitat increase, the severity of the edge effect increases causing the effect of the edge to expand. In this context, the edge effect helps to understand the interaction of different habitat types and their pressures on habitats. The fact that urban areas contain a large number of uses with different structures and functions increases the edge effect (Bennett, 2003).

The effect of the edge effect is severest in areas of intense human use. Urban areas are the leading ones. Urbanization increases fragmentation in habitats and fragmentation increases the width of the edge, consequently, the edge effect. The edge effect present in the whole urban area damages the biodiversity and ecological structure (Soule, 1991; Meffe \& Carroll, 1997).
Edge effect primarily affects the vegetation and its structure, and then the process of all living things. As well as the natural process that change with the area form, the human impact is also a factor in the changing of vegetation. Edge areas being exposed to more heat, light and wind cause changes in the natural vegetation structure of habitats (Soule, 1991). Bennett (2003) states that the change in the habitat pattern in the landscape leads to changes in the ecological process that affect the flora and fauna status. Environmental gradients certainly affect edge responses and environmental gradients are not necessarily the only causal mechanism. Some species responses to habitat edges requires the evaluation of geometric and environmental edge factors (Prevedello et al., 2013).

\subsection{Landscape structure indexes and ecological planning}

In order to measure and compare the amount of changes in landscape texture, the need for figures rises. The elements that make up the heterogeneous structure of the landscape, habitat fragmentation, spatial and structural changes are measurable. Concrete data obtained through landscape structure indexes help landscape texture and functioning to be more perceptible. By Landscape structure indexes, it is possible to interpret the changes in landscape. Thus, they are considered the basic tools of the ecological planning to structure, function and plan. On the other hand, spatial configuration indexes are used to examine the structural and spatial relationships of area types. Such indices are used to measure the extent to which ecologically adjacent areas affect each other on a spatial scale (McGarigal \& Marks, 1995).

The mosaic structure, formed by combining structurally different areas, defines landscape as heterogeneous spatial structure. Spatial relations between ecosystems vary depending on the size, shape, number and type of ecosystems, and is an important indicator of the distribution of ecological cycles and species, especially energy and matter exchange. The two variables determining the level of spatial heterogeneity are the amount of different area types in a given unit area (different habitat types) and their spatial distribution (location within the habitat) (McGarigal \& Marks, 1995).

Landscape composition, having a significant effect on ecological functioning and organisms, refers to the types and amount of landscaping mosaic. Landscape configuration refers to the physical distribution or spatial character of the lands and the spatial relations of these areas (neighborhood, proximity, distance, fragmentation) that make up the landscape. The change in the landscape structure affects mechanism, and the change in the mechanism affects the landscape structure. This dynamic interaction between structure and function plays a decisive role in the existence and continuity of living communities. The third characteristic focused on landscape ecology is the changes that occur over time in the function and structure of 
landscape mosaic (Forman \& Godron, 1986). The spatial arrangement of ecosystems across landscapes is explained by the composition and configurtion over period of time. These composition and configuration of ecosystems characterize landscapes as heterogeneous in their nature. Such changes in the composition and configuration are the results of anthropogenic activities (Wu, 2013).

Determining the existing land-use patterns and surroundings of urban areas, monitoring the direction of change in land cover in the process from past to present, and identifying the changes have become important in order to prevent the impact on natural areas and to ensure optimum-use of natural resources (Small \& Miler, 1999). Landscape dynamics are common phenomenon in the human-dominated environments whereby it can be observed that the composition and configuration between landscape elements change over time. This dynamism brings about habitat loss and fragmentation that can greatly alter ecosystem services at patch, class, and landscape levels (Tolessa et al., 2016).

As a matter of fact, the rapid development experienced in Usak City has changed the spatial distribution of the urban area and its immediate surroundings, and so the structure. Hence, understanding the current situation is important to propose future decisions and to identify change and its effects.

\subsection{Ecological network}

The intercity roads and the big public investments in the cities made cities centers of attraction. Unplanned legal and / or illegal housing settlements and industrial facilities are located in a short time around these infrastructure and investments. As a result, human impact on habitats is increasing, land use and land cover are changing fragmenting or disappearing rapidly. As a result, changes in the ecological structure cause all living things to be affected directly or indirectly (Small \& Miler, 1999). The process of growth of urban areas causes the shrinking and fragmentation of natural areas and decreases their ecological values (Bairoch, 1988). Soule (1991) stated that urbanization has transformed natural areas into smaller, isolated and poor quality areas and that the species in these areas are rapidly disappearing. It is suggested to establish connections between areas with similar vegetation characteristics and remaining areas as a way of minimizing this negativity. In order to establish these connections, also known as ecological networks, it is a step to know the vegetation structure in different land uses (Cook, 2000).

Linkage refers to the interaction of habitats with similar structural and functional characteristics. High ecological connectivity ensures the continuity of the habitat in terms of ecological cycles and species diversity. Ecological corridors provide for the ecological cycle of organisms between suitable habitat islands in fragmented landscapes (Bennett, 2003). Therefore, conservation of habitats and minimization of fragmentation effects depend on ecological connections between habitat islands.

\section{Materials and methods}

\subsection{Materials}

In this study, the urban area of Usak and its surroundings is the study area. Usak Province is located between $38^{\circ} 12^{\prime}-39^{\circ} 56^{\prime}$ northern latitudes and $28^{\circ} 48^{\prime}-29^{\circ} 57^{\prime}$ east longitudes in the Aegean Region (Figure 2).

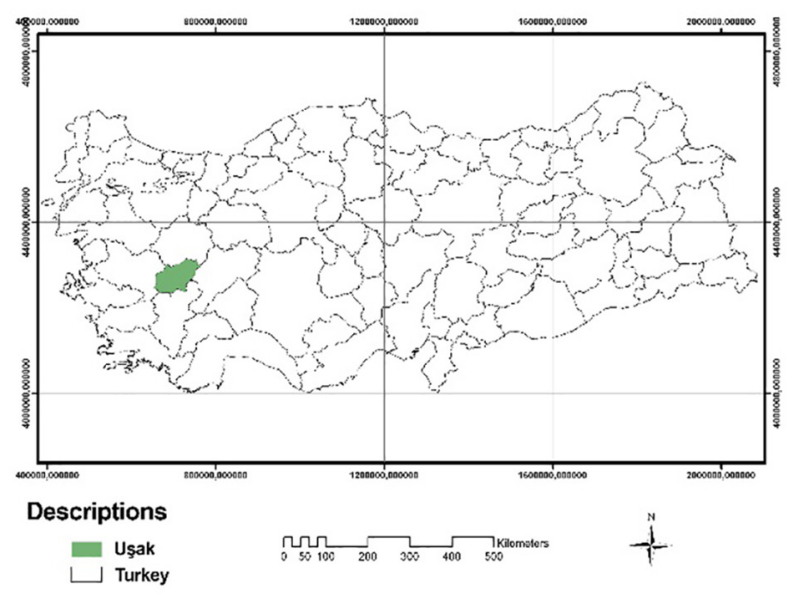

Figure 2. Location of the study area

The surface area of the study field is $5.341 \mathrm{~km}^{2}$, surrounded by Saphane Mountain $(2.121 \mathrm{~m}$ asl.) in the north, Murat Mountain (2.309 m asl.) in the northeast, and Bulkaz Mountain $(1.990 \mathrm{~m})$ in the southeast. The city of Usak is in a commercially advantageous location on the main transport artery on the Ankara (capital)-Izmir highway. Usak City is established on flat land and prone to development as the topography is not obstructive. The Usak city is one of the first cities to benefit from the railway in Turkey. In the 19th century, the railway transport of industrial products began in the city and led to easy accesible marketing. Usak airport, located $4 \mathrm{~km}$ away from the city, has been in service since 1998 .

In terms of land use capability classes in Usak; first class land covers 14.878 hectares in total and constitutes $2.8 \%$ of the province. In the city center, 5.201 hectares of land is first class land. The second class land covers 51.532 hectares and constitutes $9.6 \%$ of the province. In the city center, 17.151 hectares of land is second class. The 3rd class land in the province measures 66.247 hectares and constitutes $12.4 \%$ of the province. In the city center, 17.114 hectares of land is $3 \mathrm{rd}$ class land. The 4 th class land is 68.557 hectares and constitutes $12.9 \%$ of the province. In the city center, 20.526 hectares of land is 4th class land. Across the province, 5th class land is 311 hectares and constitutes $0.05 \%$ of the province. The sixth class land is 91.120 hectares and constitutes $17.1 \%$ of the province. In the city center, 19.653 hectares is the 6 th class land. The 7 th class land is 224.439 hectares and constitutes $42 \%$ of the province. In the city center, 60.635 hectares of land is classified as 7 th class land. The 8th class lands in the province takes up 16.728 hectares and constitutes $3.1 \%$ of the province. In the city center, 1.173 hectares of land falls 
into 8th class land classification (General Directorate of Rural Services, 1997). The city of Usak is located between the Aegean and Central Anatolia regions. Due to its geographical location, a coastal climate and a continental climate prevail in the city. The average annual temperature is $12.3{ }^{\circ} \mathrm{C}$, the annual rainfall is $531.3 \mathrm{~mm}$, the average annual relative humidity is $57.2 \%$ and the average relative humidity is $64 \%$ (Usak Meteorology Directorate, 2008).

The city of Usak has always been commercially important with its geopolitical value, due to main roads extending from Western Anatolia to Central Anatolia. The industrial facilities established in different sectors of the city have made the city economically strong. Industry and businesses led to migrations from rural areas and from other cities. When Usak gained its provinencal status, the migration rate was only $4 \%$, yet in 2000 , this percentage increased to $16 \%$ by quadroupling. In 1955, 6.619 citizens and in the year 2000, 52.178 citizens were recorded to migrate to the city. In the 45 -year- period, the population increase by migration is observed to be as high as 45.88 per thousand (State Statistics Institute [SSI], 2008) (Table 1). After the city gained provincial status in 1953, new industrial and commercial areas such as leather and ceramic industries were established with increasing investments during 1954 and 2004, in addition to its leading industry of weaving for hundreds of years. For this reason, the population has increased rapidly and hence urbanization has accelerated.

Table 1. Usak City population status by years (SSI, 2008)

\begin{tabular}{|c|c|c|c|c|c|}
\hline Years & $\begin{array}{c}\text { Total } \\
\text { Popu- } \\
\text { lation }\end{array}$ & $\begin{array}{c}\text { Population } \\
\text { Increase } \\
\text { Rate (in } \\
\text { Thousands) }\end{array}$ & $\begin{array}{c}\text { Center } \\
\text { Popu- } \\
\text { lation }\end{array}$ & $\begin{array}{c}\text { Growing } \\
\text { Popu- } \\
\text { lation }\end{array}$ & $\begin{array}{c}\text { Yearly } \\
\text { Inc- } \\
\text { rease } \\
\%\end{array}$ \\
\hline 1950 & 117.655 & 18.34 & 19.636 & 857 & 0.91 \\
\hline 1955 & 165.374 & 68.10 & 23.496 & 3.860 & 3.93 \\
\hline 1970 & 207.512 & 17.06 & 46.392 & 10.876 & 6.12 \\
\hline 1990 & 290.283 & 13.55 & 105.270 & 17.003 & 3.85 \\
\hline 2000 & 322.313 & 10.46 & 137.001 & 31.731 & 3.01 \\
\hline 2007 & 334.115 & 5.14 & 172.709 & 35.708 & 3.72 \\
\hline
\end{tabular}

The leather and leather products industry in Usak has a 600-year history (Usak Chamber of Commerce and Industry, 2008). The development of carpets and rug production in Usak began in the 16th century. The railroad (established in 1867) and electricity (established in the beginning of the 1900s) had a positive impact on the development of the city (Atalay, 1967). The first yarn factory was founded in 1905 in Usak. Considering there were very few factories throughout the country during these years, the importance of Usak industry can be better understood. Main manufactured goods in this sector are cotton weaving, dyeing printing, cotton yarn, acrylic yarn, carpet, rug and blanket rope, plush blanket, socks, knitwear, bed linen, fabric, polyester fiber, and bandage production. In 1926, Turkey's first sugar factory was established in Usak (Usak Chamber of Commerce and Industry, 2008).

\subsection{Methods}

In this study, it is aimed to define the natural and cultural structure of the city. 1/1000 scale zoning plans belonging to the years of 1953, 1989, 1994 and reports of Usak City, $1 / 25000$ scale topographic map prepared by the General Command of Mapping, 1/25000 scale soil map, 1/5000 scale forest asset map prepared by Forest Management Directorate were used. 1/60000 scale 1954 monoscopic aerial photograph, 1/20000 scale 1971 monoscopic aerial photograph, 1/35000 scale 1994 monoscopic aerial photograph and the orthorectified satellite image of Ikonos dated 09.03.2004 were used in order to determine urban area boundaries according to data years. Edge analysis was utilized in the study which aims to reveal the spatial and structural changes in the urban area and its vicinity in the historical process. Aerial photographs, satellite imagery, rectification of other raster maps and images, mapping of urban land uses and database query operations were carried out using the geographical information system in the ArcMap 9.2 software. Figure 3 shows the determination of urban area boundary according to data years.

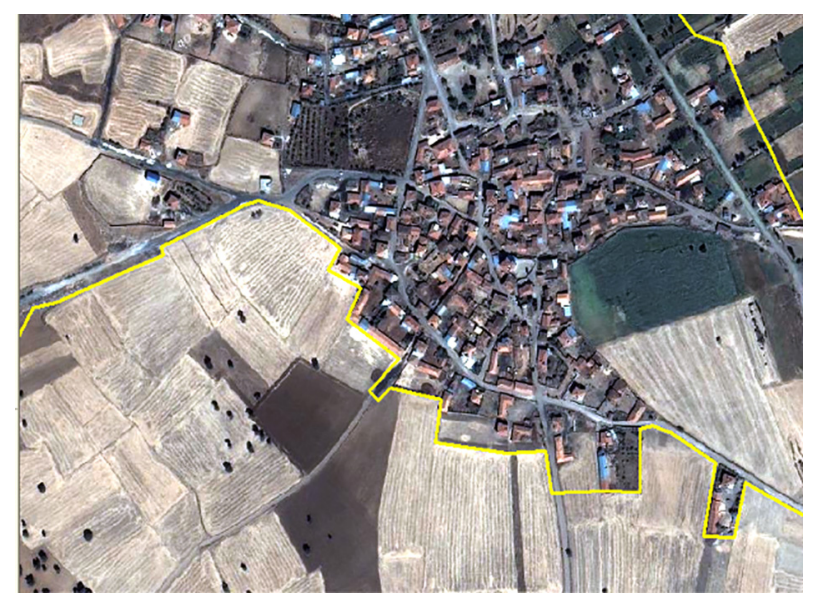

Figure 3. Geographical coordination of data and creation of urban area boundary

In the study, boundary specifications of the urban area covering the data years $(1954,1971,1994,2004)$ is based on the unity of the areas; selected as the main criteria without interrupting the structural continuity of the city. Also included in the urban area border are the areas which are not yet constructed, yet parceled, are surrounded by roads and are infrastructured; exposed to a direct human effect and lost their agricultural and natural features. In terms of urban boundry, this study also evaluates the agricultural activities on partial and densly urbanized agricultiral areas within the city. Specification accuracy was evaluated as field observations by field studies. After specifying the urban area boundaries, the usage types defining the city for each data year were determined and area usage maps were created.

Structural and functional status of the urban areas have been examined as the main criteria for the classification of urban areas. Types of land use are primarily divided into 
main categories. The main categories of structures and functions have been specified by taking the fundamental differences into account (American Planning Association [APA], 2003).

The nature of environmental uses determines the ecological quality of natural areas. Edge analysis focuses on the use of environmental areas where area types interact directly with each other. The higher the structural and functional differences of the natural areas with the use of the surrounding areas, the more their ecological quality is under threat (Meffe \& Carrol, 1997; Esbah, 2001). Edge analysis aims to obtain data to understand the structural compatibility of a habitat area with surrounding habitats based on the edge effect concept (Forman, 1995; Deniz, 2005). The fact that environmental use is so important on the ecological quality of natural areas makes edge analysis a valid method for understanding the impacts of natural areas (Esbah, 2001).

The enclosure of natural areas with the use of different structures, cause negative conditions of edge effects in these areas. The increasing difference in the structure at the border, and the expansion of different types of areas around natural areas, deteriorate the ecological characteristics of the natural area by causing a continuous diminish (Dramstad et al., 1996).

To prove the impact of urban areas on surrounding areas, it is crucial to classify all types of land-use differing structurally from one another. The method for mapping operations was by digitizing on the screen. The numerical data obtained are formulated according to Eq. (1):

$$
\mathrm{S}=\sum\left(\mathrm{AS}_{\mathrm{O}} \times \mathrm{S}_{\mathrm{K}}\right)
$$

Equation 1. "Edge analysis" equation

$S$ - Edge analysis index value; $\mathrm{AS}_{\mathrm{O}}-\%$ Ratio of area usage type boundary length to total perimeter length; $S_{K}-$ Area usage type structure coefficient.

$S_{K}$ in the equation is used as the correction coefficient to reveal the differences in the structures of the areas. Structure coefficient $\left(S_{K}\right)$ is the coefficient determined by Deniz (2005) according to the proportional amount and vegetation structure index value of permeable soil surfaces.

In this study, the contribution of each field usage type to ecological quality was taken as a basis in determining the structure coefficient (Table 2). In order to specify this level, Forman (1995) mentions ecological quality and proposes four criteria (production level close to nature, level of biodiversity, soil, water).

Table 2 shows the highest values in terms of permeability of agricultural land and empty parcels. The high permeable surface rates indicate the ecological importance of the type of land-use, and its impact on natural landuse types. The high rate reflects the naturalness value of the land usage type. Vegetation structure index values indicate the naturalness value of the vegetation structure in the land-use type, and thus, its effect on the natural
Table 2. Structure coefficient values of the land use types (Deniz, 2005)

\begin{tabular}{|l|c|c|c|}
\hline Types of land use & $\begin{array}{c}\text { Permeable } \\
\text { surface (\%) }\end{array}$ & $\begin{array}{c}\text { Vegetation } \\
\text { structure } \\
\text { index values } \\
\text { (\%) }\end{array}$ & $\begin{array}{c}\text { Structure } \\
\text { Coefficient } \\
\text { (Sk) }\end{array}$ \\
\hline $\begin{array}{l}\text { Open green } \\
\text { spaces }\end{array}$ & 62.4 & 44.8 & 53.6 \\
\hline River beds & 77.3 & 44.7 & 61.0 \\
\hline Military lands & 59.0 & 55.4 & 57.2 \\
\hline Empty parcels & 95.9 & 58.1 & 77.0 \\
\hline Public spaces & 44.9 & 53.4 & 49.2 \\
\hline $\begin{array}{l}\text { Urban agricultural } \\
\text { fields }\end{array}$ & 74.9 & 62.4 & 68.6 \\
\hline Residential areas & 59.3 & 55.7 & 57.5 \\
\hline Parks & 43.4 & 52.8 & 48.1 \\
\hline Industrial areas & 19.7 & 33.8 & 26.8 \\
\hline Agricultural fields & 97.0 & 62.5 & 79.7 \\
\hline Railways & 44.6 & 53.2 & 48.9 \\
\hline Commercial areas & 20.4 & 38.7 & 29.6 \\
\hline Roads & 28.0 & 56.3 & 42.1 \\
\hline
\end{tabular}

area. Land-use types with high index value of vegetation structure are considered to have positive effect on ecological structure with the presence of natural plant species. When the types of urban land-use are evaluated according to their vegetation cover, agricultural areas take the first place. Empty parcels, river beds, urban agricultural areas and open green spaces are other important land-uses.

Due to the unique structure of each land use type, the level of its effect varies. In order to determine these differences, the land use types at the urban boundary were mapped, the numerical data recorded in the GIS database were calculated; first, for the total perimeter of the urban area, and for the proportional amounts of the land-use types within the total length for each data year. As a result of the edge analysis, the analysis values vary between 0 and 1. If the environmental use is surrounded by a completely incompatible structure, the value approaches 0 , and as the level of compatibility in the structure increases, the value approaches 1 .

\section{Results and discussion}

\subsection{Results}

The urban area of Usak was 366.5 hectares in 1954 (Figure 4), 743.5 hectares in 1971 (Figure 5), 2424.9 hectares in 1994 (Figure 6) and 4833.3 hectares in 2004 (Figure 7). The urban area of Usak city increased by $102.9 \%$ between 1954-1971 (with an increase of $377.1 \mathrm{ha}$ ), 226.1\% between 1971-1994 (with an increase of $1681.2 \mathrm{ha}$ ) and $99.3 \%$ between 1994-2004 (with an increase of 2408.5 ha). Thus, 1971-1994 became the period in which the highest expansion for the urban growth took place by $226.1 \%$. 


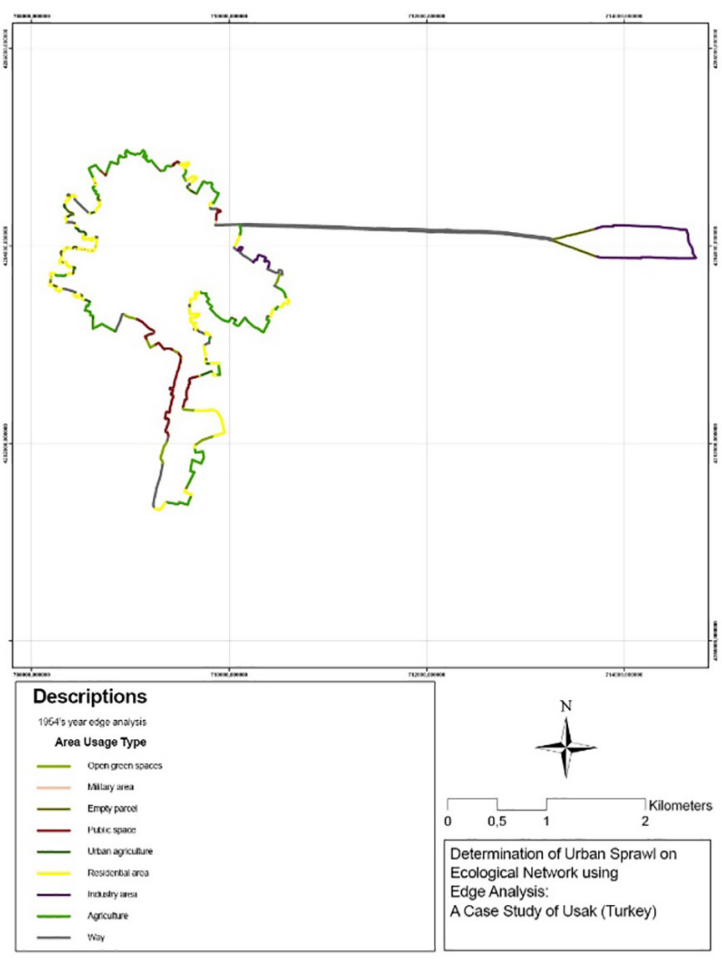

Figure 4. The edge analysis map of 1954

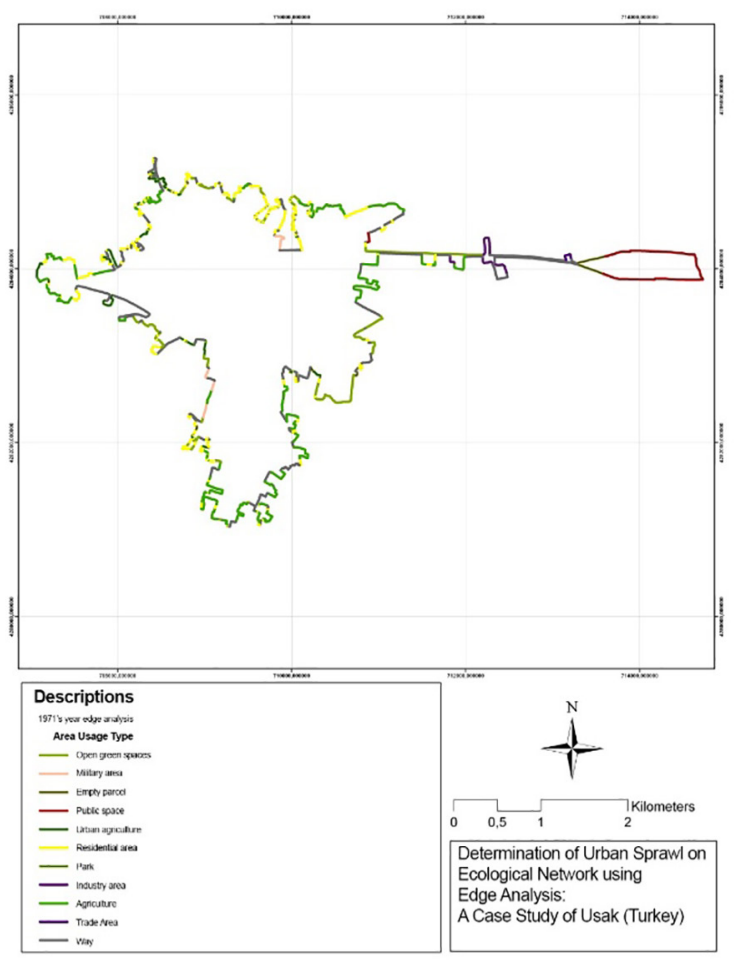

Figure 6. The edge analysis map of 1994

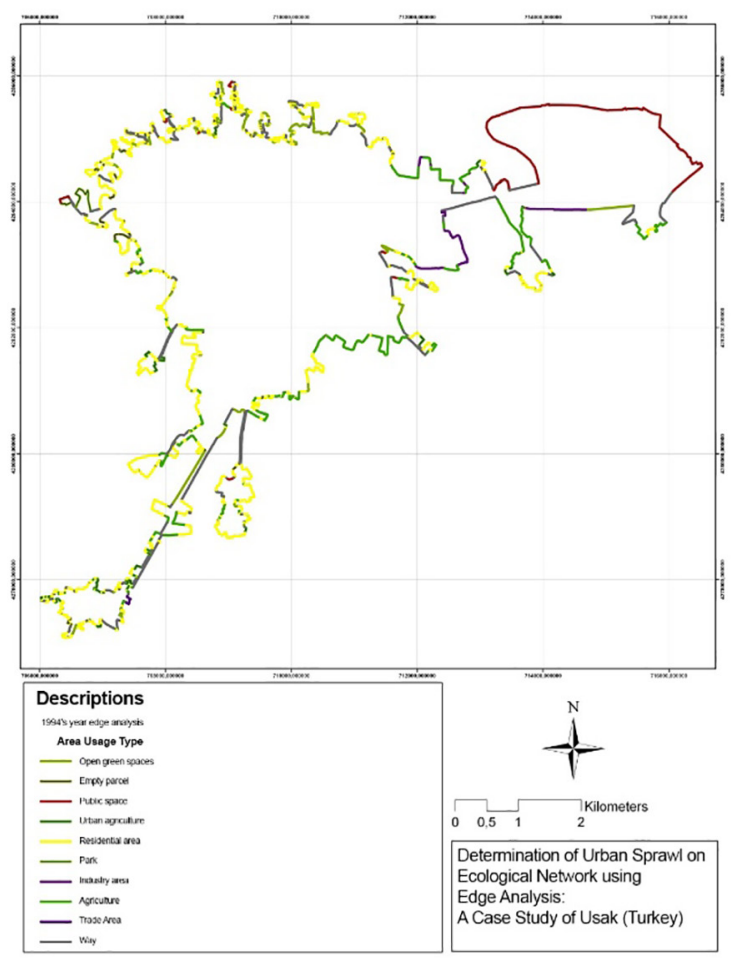

Figure 5. The edge analysis map of 1971

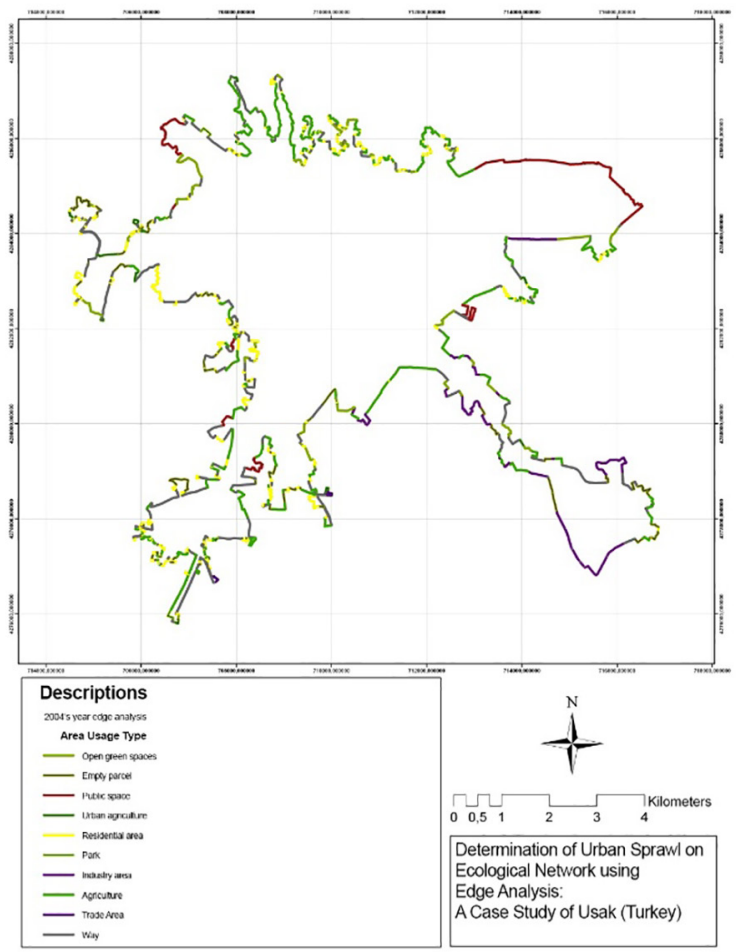

Figure 7. The edge analysis map of 2004 
Between the years 1954-1971, the city developed in all directions, except for the northern direction because of limited development area. Between the years 1971-1994, with the acceleration of industry and business lines, an important factor in urban growth, the city expanded towards almost every direction. The rapid increase in public investments in the city during the same years impacted the growth of the city leading an intense urban development directed towards the east, west and south. The increase in business lines in industry and trade created a demand for housing due to migration. Consequently, housing and industrial area-uses were on the rise.

Urban area types contribute to the continuity of natural life in terms of their unique structures and ecological values (Shaw et al., 1996). Edge analysis focuses on the types of land use at the urban area boundary. Taking the city boundary as the basic criterion, the similarity or contrast between the type of land use within the border, and the type of land use outside the border, in terms of natural structure is measured by edge analysis. While land-use types with structure values close to each other are important in terms of a harmonious urban texture, neighboring land use differring from one another cause a discordant mosaic which damages the natural area in the course of time. The importance of edge analysis is to predict the potential development trend of the city and the rate of land use.

Types of land-use on the outer walls of Usak urban area, form the basis of edge analysis which is used to determine the neighboring areas as border usage types affect the growth of the city, and the types of land. For instance, a neighbouring industrial use area at the border will probobly be added within the border, to the present industrial area, of the city when there is a change or growth in the city border. Thus, the evaluation of edge analysis is important in terms of monitoring the future growth direction, and usage types of the city and affecting the urban planning decisions.
The edge analysis index results are obtained from the edge analysis equation (Eq. (1)). The proportional amounts and structure coefficients of the land use types, which are located at the boundary of the urban area to the total surrounding area are put into place in the equation. This process was repeated for each data year. The following are the edge anaylsis maps for the city of Usak for 1954, 1971, 1994, and 2004.

Table 3 shows the data of the edge analysis for 1954 . Data were obtained by mapping the land-use types forming the border over the city boundary of 1954 . The result of the boundary index was 0.544 . When the table is examined, the most important factor affecting the index value is the roads that constitute the city boundary, and provide access to the industrial areas in the city wall. Roads constituted $32.3 \%$ of the total limit. Agricultural areas also significantly impacted on the formation of the edge analysis value of 1954 with a share of $19.3 \%$. The $18 \%$ representation of the residential areas in the city wall was decisive in the analysis value. Industrial areas with a rate of $9.7 \%$, and public areas with a rate of $8.4 \%$ were located at the border of the urban area in 1954. This is an indication that these types of usage are located on the wall of the city center in the relevant data year.

Table 4 presents the data of the edge analysis for 1971. Data were obtained by mapping the land-use types forming the border over the city boundary of 1971 . Edge index result was 0.576 . When the table is examined, the most important factor affecting the index value is the roads that constitute the city boundary with $28.3 \%$ of the total limit. In addition, agricultural areas affect the formation of the edge analysis value of by taking $23.7 \%$ share of the border. Residential areas are determinative in the analysis value with a margin share of $18.1 \%$. The ratio of open green spaces over the total limit is $11.9 \%$. When the 1971 urban border is compared with the previous data year, it is clear that the ratio of industrial areas at the border decreased,

Table 3. The edge analysis of the year 1954

\begin{tabular}{|c|c|c|c|c|}
\hline Types of land use & $\begin{array}{c}\text { Land Use Circumference } \\
\text { Length }(\mathrm{km})-\mathrm{A}\end{array}$ & $\begin{array}{c}A s_{o}-\% \\
\text { A/B rate } \\
\text { Ratio of area usage type } \\
\text { boundary length to total } \\
\text { perimeter length }\end{array}$ & $\begin{array}{c}S_{k} \\
\text { Area usage type struc- } \\
\text { ture coefficient }\end{array}$ & $\begin{array}{c}S \\
\text { Edge analysis index } \\
\text { value }\end{array}$ \\
\hline Open green spaces & 1.1 & 3.9 & 53.6 & 2.1 \\
\hline Military lands & 0.03 & 0.1 & 57.2 & 0.1 \\
\hline Empty parcels & 1.5 & 5.5 & 77.0 & 4.2 \\
\hline Public spaces & 2.4 & 8.4 & 49.2 & 4.1 \\
\hline Urban agricultural fields & 0.8 & 2.8 & 68.6 & 1.9 \\
\hline Residential areas & 5.1 & 18.0 & 57.5 & 10.4 \\
\hline Industrial areas & 2.7 & 9.7 & 26.8 & 2.6 \\
\hline Agricultural fields & 5.4 & 19.3 & 79.7 & 15.4 \\
\hline Roads & 9.1 & 32.3 & 42.1 & 13.6 \\
\hline $\begin{array}{l}\text { Total Boundary Length } \\
(\mathrm{km}) \text {-B }\end{array}$ & 28.1 & $S=\sum\left(A s_{o} \times S_{k}\right)$ & \multicolumn{2}{|c|}{$\sum S=\mathbf{5 4 . 4}$} \\
\hline
\end{tabular}


Table 4. The edge analysis of the year 1971

\begin{tabular}{|l|c|c|c|c|}
\hline \multicolumn{1}{|c|}{ Types of land use } & $\begin{array}{c}\text { Land Use Circumference } \\
\text { Length (km)-A }\end{array}$ & $\begin{array}{c}A s_{0}-\% \\
\text { A/B rate } \\
\text { Ratio of area usage type } \\
\text { boundary length to total } \\
\text { perimeter length }\end{array}$ & $\begin{array}{c}S_{k} \\
\text { Area usage type struc- } \\
\text { ture coefficient }\end{array}$ & $\begin{array}{c}\text { Edge analysis index } \\
\text { value }\end{array}$ \\
\hline Open green spaces & 5.0 & 11.9 & 53.6 & 6.4 \\
\hline Military lands & 0.7 & 1.6 & 57.2 & 0.9 \\
\hline Empty parcels & 0.9 & 2.1 & 77.0 & 1.6 \\
\hline Public spaces & 2.7 & 6.3 & 49.2 & 3.1 \\
\hline Urban agricultural fields & 2.2 & 5.2 & 68.6 & 3.6 \\
\hline Residential areas & 7.7 & 18.1 & 57.5 & 10.4 \\
\hline Parks & 0.1 & 0.2 & 48.1 & 0.1 \\
\hline Industrial areas & 0.9 & 2.2 & 79.8 & 0.6 \\
\hline Agricultural fields & 10.0 & 23.7 & 29.6 & 18.9 \\
\hline Commercial areas & 0.2 & 0.4 & 42.1 & 0.1 \\
\hline Roads & 11.9 & 28.3 & & $\sum S=\mathbf{5 7 . 6}$ \\
\hline $\begin{array}{l}\text { Total Boundary Length } \\
\text { (km)-B }\end{array}$ & $\mathbf{4 2 . 3}$ & $S=\sum\left(A s_{o} \times S_{k}\right)$ & & 11.9 \\
\hline
\end{tabular}

indicating industrial areas remaining within the city druring city growth. The decrease in the proportion of public spaces at the border depicts the development of new types of urban area usages around public spaces, and the remaining of the public spaces within the border.

Table 5 puts forward the data of the edge analysis for 1994. Data were obtained by mapping the land-use types forming the border over the city boundary of 1994. The result of the edge index was 0.561. Residential areas accounted for $38.2 \%$ of the total limit. Roads affected the analysis value by forming $22.1 \%$ of the total limit. In the 1994 urban area boundary, there is a direct relationship between residential areas and roads. Agricultural areas reduced to $14.7 \%$ of the total border while open green spaces made up $7.9 \%$ of the total border, and public spaces $7.7 \%$. Due to the growth of the city, and developing needs, the use of public spaces on the border took place.

Table 6 shows the data of the edge analysis for 2004 . Data were obtained by mapping the land-use types forming the border over the city boundary of 2004. Edge index result was 0.580 . When the table is examined, the most important factor affecting the index value is agricultural areas. In 2004, agricultural areas constituted $26 \%$ of the total border which is a crucial indicator the city growing in the direction of agricultural areas. On the other hand, roads significantly affected the analysis value by making up $25.8 \%$ of the total limit. The impact of roads on the city

Table 5. The edge analysis of the year 1994

\begin{tabular}{|c|c|c|c|c|}
\hline Types of land use & $\begin{array}{l}\text { Land Use Circumference } \\
\text { Length }(\mathrm{km})-\mathrm{A}\end{array}$ & $\begin{array}{c}A s_{o}-\% \\
\text { A/B rate } \\
\text { Ratio of area usage type } \\
\text { boundary length to total } \\
\text { perimeter length }\end{array}$ & $\begin{array}{c}S_{k} \\
\text { Area usage type } \\
\text { structure coefficient }\end{array}$ & $\begin{array}{c}S \\
\text { Edge analysis index } \\
\text { value }\end{array}$ \\
\hline Open green spaces & 7.7 & 7.9 & 53.6 & 4.2 \\
\hline Empty parcels & 1.7 & 17 & 77.0 & 1.3 \\
\hline Public spaces & 7.5 & 7.7 & 49.2 & 3.8 \\
\hline Urban agricultural fields & 3.2 & 3.3 & 68.6 & 2.3 \\
\hline Residential areas & 37.1 & 38.2 & 57.5 & 22.0 \\
\hline Parks & 1.2 & 1.2 & 48.1 & 0.6 \\
\hline Industrial areas & 2.8 & 2.9 & 26.8 & 0.8 \\
\hline Agricultural fields & 14.2 & 14.7 & 79.7 & 11.7 \\
\hline Commercial areas & 0.2 & 0.2 & 29.6 & 0.1 \\
\hline Roads & 21.5 & 22.1 & 42.1 & 9.3 \\
\hline $\begin{array}{l}\text { Total Boundary Length } \\
(\mathbf{k m}) \text {-B }\end{array}$ & 97.2 & \multicolumn{2}{|c|}{$S=\sum\left(A s_{o} \times S_{k}\right)$} & $\sum S=\mathbf{5 6 . 1}$ \\
\hline
\end{tabular}


Table 6. The edge analysis of the year 2004

\begin{tabular}{|c|c|c|c|c|}
\hline Types of land use & $\begin{array}{c}\text { Land Use Circumference } \\
\text { Length }(\mathrm{km})-\mathrm{A}\end{array}$ & $\begin{array}{c}A s_{o}-\% \\
\text { A/B rate } \\
\text { Ratio of area usage type } \\
\text { boundary length to total } \\
\text { perimeter length }\end{array}$ & $\begin{array}{c}S_{k} \\
\text { Area usage type } \\
\text { structure coefficient }\end{array}$ & $\begin{array}{c}S \\
\text { Edge analysis index } \\
\text { value }\end{array}$ \\
\hline Open green spaces & 9.9 & 7.7 & 53.6 & 4.1 \\
\hline Empty parcels & 10.8 & 8.4 & 77.0 & 6.5 \\
\hline Public spaces & 9.3 & 7.2 & 49.2 & 3.5 \\
\hline Urban agricultural fields & 2.9 & 2.3 & 68.6 & 1.6 \\
\hline Residential areas & 19.0 & 14.8 & 57.5 & 8.5 \\
\hline Parks & 0.8 & 0.6 & 48.1 & 0.3 \\
\hline Industrial areas & 8.5 & 6.6 & 26.8 & 1.8 \\
\hline Agricultural fields & 33.6 & 26.0 & 79.7 & 20.7 \\
\hline Commercial areas & 0.6 & 0.5 & 29.6 & 0.1 \\
\hline Roads & 33.3 & 25.8 & 42.1 & 10.9 \\
\hline $\begin{array}{l}\text { Total Boundary Length } \\
(\mathbf{k m})-B\end{array}$ & 128.8 & \multicolumn{2}{|c|}{$S=\sum\left(A s_{o} \times S_{k}\right)$} & $\sum S=\mathbf{5 8 . 0}$ \\
\hline
\end{tabular}

is due to new roads connecting the new urban land uses. Moreover, residential areas occupied an $14.8 \%$, empty parcels, open green spaces and public spaces also played a role in determining the analysis with approximately equal values. When compared to the previous data year, a $6.6 \%$ industrial area increase is present on the border upon new industrial areas serving.

\subsection{Discussion}

Esbah (2001), in her study in Phoenix, Arizona, found that when natural areas were surrounded by unsuitable landuse types, these areas became smaller, and isolated due to fragmentation, and therefore caused the degradation of the ecological quality of the areas despite the protection status. The recommendations developed as a result of the study that the ecological areas should be surrounded by more compatible land-use types. Esbah (2001), proposed to create buffer zones around these areas to strengthen the interconnection of open green spaces in an open green space system, and to develop a biodiversity conservation management and planning system.

Jim and Chen (2003) in Nanjin, China, envisaged the encirclement of cities with a green area matrix that accommodates different habitats for an ideal landscape configuration at regional scale, considering a more flexible urban sprawl, green area acquisition, wildlife habitats and environmental gains for the future, their study emphasizes an integrated open green space network to be established. The focus was on improvement of landscape and environmental quality, and area characteristics and transportation priorities rather than than the traditional development model. The study concludes with the emphasis that the curved and recessed interface of the urban-rural area establish a longer connection line, and so that the natural areas can penetrate more within the city.
In the 2003 study, Lioubimtseva (2003) examined the impacts of land-use in nature, various large-scale lands (semi-natural forests, forests, steppes, farmlands, and urban landscapes) in the European part of Russia. In the study, SHAPE $=(4 \pi \mathrm{Ai} \times 100) / \mathrm{P}_{\mathrm{i}}^{2}$ index was used to examine the edge effect. Ai are patch areas and Pi are their surroundings. $\pi=3,14519$. (=100 SHAPE) is the maximum value for circular patches. As it approaches 0 , patches decrease (Gulinck et al., 1993).

Patton (1975) proposed the introduction of wildlife species and the provision of habitats in efforts to develop alternative habitats as a tool for the development of border areas according to the diversity index. The other basic index used in this study is fractal size. The size and shape of the patches are evaluated by the fractal index (Pax-Lenney $\&$ Woodcock, 1997). Fractal dimension $>1$ represents the character of a two-dimensional patch. Approaching the fractal dimension to 1 means very simple shapes (such as circles/squares). Complex shapes are expressed with values approaching 2. Complex shaped dominant patches show heterogeneity of land cover. However, landscape evaluations based on the indexes reavealed that the fragmented areas increased the edge effect and that effect increased as the area grew. The study revealed that determination of land cover ratio is effective in measuring spatial losses.

Deniz (2005) examined the urban development of Aydin between 1937, 1960, 1977 and 2002, and evaluated the transformations in urban land usage in the data years with landscape structure indexes. The study put forward that urban development was in housing, industrial and commercial uses; revealing agricultural areas to face the negative impact of urban development. With the vegetation cover coating conditions analysis, it was found that the areas with the highest value were natural areas, agricultural areas and empty parcels. Also, with the edge analysis and permeable surface analysis, agricultural and 
natural areas, and empty parcels had the highest value. The study points out the negative impact of population and urbanization on natural areas in qualitative and quantitative terms, and pointed out that urban planning should be maintained in harmony with natural landscape values.

According to the study for three separate dates, Ji et al. (2006) specified the land-use status for Kansas city, USA in terms of spreading character and the amount of spread. Satellite images of 1972, 1985 and 1999 were analysed, and the city was examined in two parts; under the vegetation cover, and residential areas and commercial areas. As a result, although a significant decrease in vegetation cover was determined, an increase in the settlements and commercial areas was evident.

Usak Province having easy access to major cities and ports by road, rail and air transport was cited in the report titled "Economic Development of Usak Province" (Sen et al., 2006). This access promotes the development of the city in industry, trade and other sectors, also making the city prominent in education and entrepreneurship since the beginning of the Republic. Usak City has made very successful leaps in economic development and industrialization in recent years with its tradition of industry and trade.

In the evaluation of XX. century industrialization and urbanization process Çakmak (2008), emphasized that Usak City was the traditional carpet production center before XIX. century. Indeed, at the beginning of the 20th century 7,000 people (population of about 13000 total) found employment opportunities in the carpet sector in XX. early century in Usak. After the 1870 s, a certain

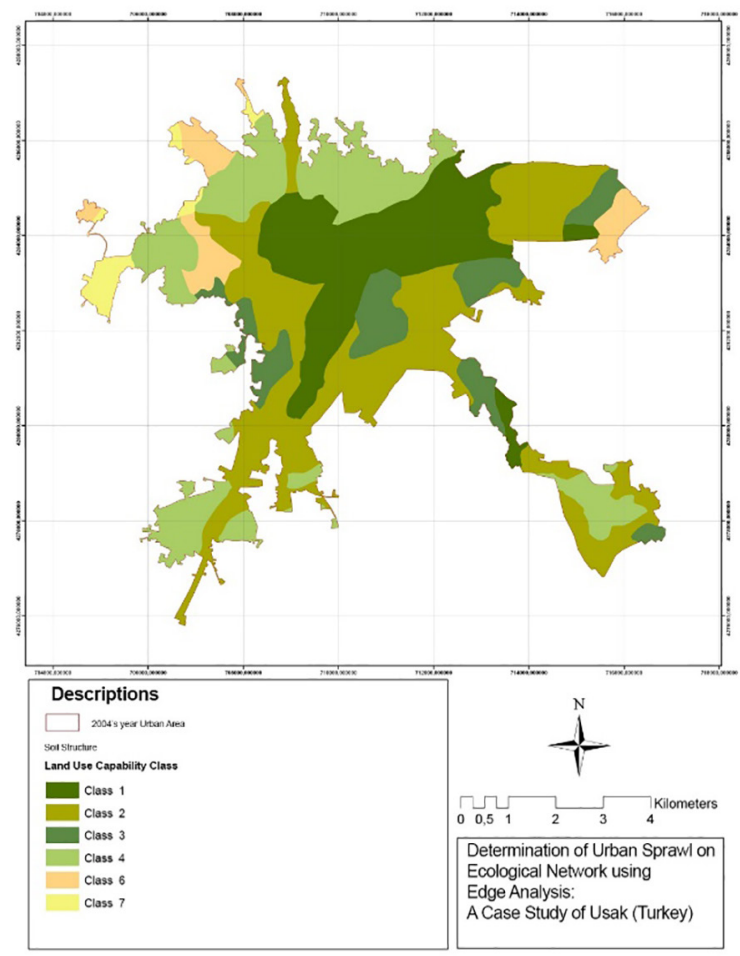

Figure 8. Usak urban area land-use capability classes on 2004 data year increase was observed in the number of factories established by private entrepreneurs. The ease of transportation by the existing railway, Ankara-Istanbul main highway and Izmir port has encouraged the development of industry and business lines in the city.

Regarding the study area, when similar studies are examined, there lays a direct proportion between city growth and expansion, and economical development and with the increase in population, city borders tend to expand to natural areas. Between 1954 and 2004, there was a significant change in the expansion of the urban border and the transformation of land-use in Usak. When the growth curve within the city was analyzed, urbanization was declared to continue depending on the years to come. While the city attracted attention with its small city structure, became a province in 1954, it reached a point where the industry became known throughout the country in 2004 and even with some of its products, it crossed the borders of the country, and thus attracted the population of investors and workers.

The maps and numerical data obtained from the study show that the city of Usak is mostly surrounded by agricultural areas and open green spaces. The structure coefficients of agricultural areas and open green spaces are high. Therefore, these areas are of primary importance in ecological planning actions. The effect of current urbanization on land use capability class can be seen in Figure 8. Looking at the land use capability class around the study area (Figure 9), urban sprawl can be directed in the future. This is important for the protection of soil and precious land.

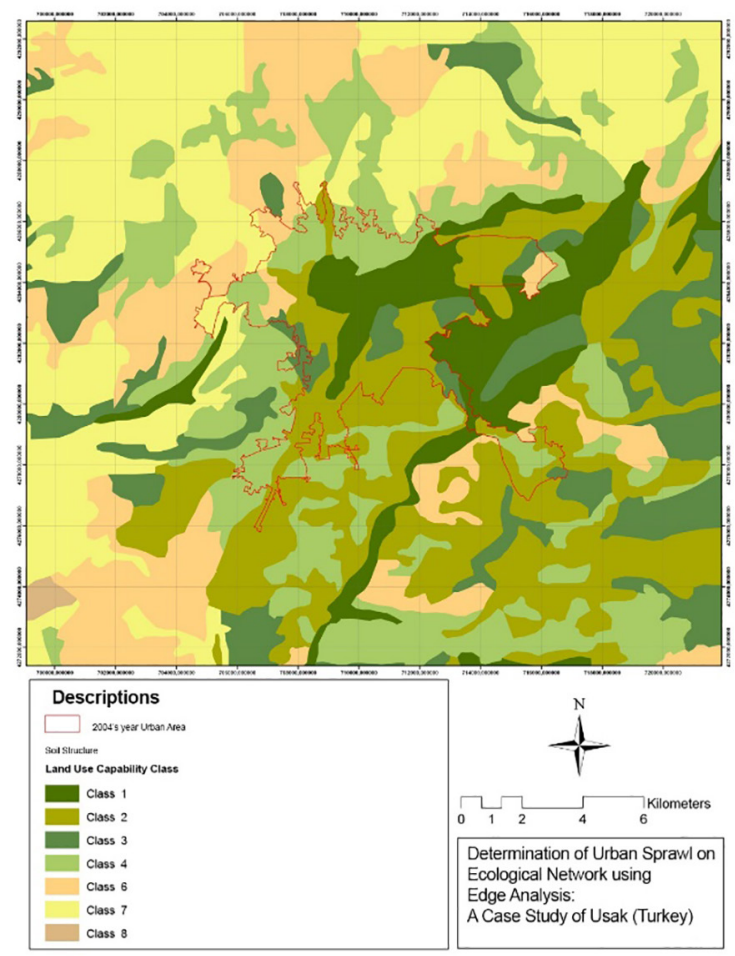

Figure 9. Land capability classes forming the vicinity of Usak City 
Studies related to the transformation of urban areas have shown that the high natural value of the adjacent areas in terms of structural harmony and neighboring with similar areas is an effective way to protect such natural areas. In this scope, agricultural areas, open green spaces, empty parcels, urban agricultural areas, military areas, parks, river beds and railways constitute compatible areas and corridors. In the ecological planning approach, agricultural areas and open green spaces adjacent to the boundaries of the urban area, both serve as a buffer; preventing uncontrolled expansion of the city, and provide the transition connecting the other urban open green spaces and corridors. In the coming years, providing the city to be growth-protected, the open green spaces in and out of the city, and the existence of such natural areas will be preserved, their continuity will be ensured and the ecological value of the open green spaces will be increased. These areas will provide the connections for the exchange of substances and energy that will ensure the functioning of natural cycles. At the same time, this system will improve the quality of life of the city, and provide social, educational and recreational opportunities for the citizens. Thus, it is important to know the soil type and land capability classes around the last border of the city. Therefore, it is recommended that the city develops by preserving important lands with the future environmental plan.

It is assumed that the results of this study conducted in the urban area of Usak may accelerate the studies for the identification of the species and populations of the agricultural areas, and open green spaces located in the urban border, and away from the urban area and the differences in their structures.

\section{Conclusions}

Study findings prove the urban area of Usak has grown continuously during the fifty years between 1954-2004, and undergone a significant change in terms of urban area border use. With the development of the industrial and trade sectors, a rapid growth of the labor force population triggered the growth of the city. Thus, the social and economic developments brought a new face to Usak.

An important feature in the urban area between the years 1971-1994, and 1994-2004 is that the city grew rapidly in all directions by new residential units. Over time, the housing use in the urban areas caused a disintegration of the agricultural areas and open green spaces to gradually or directly transform into less ecological land-use, resulting in a negative edge effect provoking a poor quality change in natural areas. Thus, the fragmented agricultural areas within the boundaries of the urban area lost their agricultural qualities and caused an unusual growth of the urban area boundary. Direct proportioned with the years, these fragmented natural areas remaining in the city, prepared the foundation for the process of decline and disappearance.
Urban growth between 1954-2004 was present on highways connecting the city to other provinces; especially on the the Ankara-Izmir highway and the Usak-Denizli highway routes where the city was shaped and developed. Apart from industrial facilities, another important developmental encourgement leading the city to grow more in the east, west and south was the establishment of the state university, while the growth in the north direction was less particular due to the topographic structure of the land.

Edge analysis index values calculated by permeable surface analysis and structure coefficients provide important information regarding the impact on urban area boundary, and environmental-use. Edge analysis index was originally produced to obtain data for the protection of natural areas around the city. It was also used to understand the pressure exerted by the use of the area around natural areas.

In this analysis, the effect of the developments in the city towards different ecosystems outside, is to be examined. When the structure coefficients are taken into consideration, the agricultural-land having the highest coefficient is the land-use type, and the empty parcels take the second place. The permeability level of these areas, so the presence of soil structure, and plant material coverage rates are high. The level of permeability is important in terms of ecological water, nutrient and air cycles, and finding the habitat of plant and animal diversity.

As a fact, empty parcels and urban agricultural areas have a high coefficient when the permeability levels are considered. However, empty parcels and urban agricultural areas were rapidly transformed into other types of land-use during the data years. Considering the fact that they are valuable elements for the establishment of an urban open green space system, and their role in ensuring a connection with the out-of-city open green spaces, their importance becomes more apparent.

Empty parcels constitute an important step of the residential construction process, specifically those located in close proximity to ecological corridors and natural areas are of particular importance. Adding empty parcels to the urban open green space system will not only serve the continuity of the open green spaces, but will also positively affect the size of the existing ones.

Edge analysis results provide an understanding of the contrast between the urban area, and the structure surrounding the city by giving an idea about the compatibility of the city with its environment. The high contrast value indicates the city being incompatible with its surroundings, and the low contrast indicates that the city is compatible with its surroundings. This function serves as a tool for assessing the ecological quality of the city. The analysis also provides important data for understanding the changes in the city wall.

Examining the edge analysis data of 1954, the result of the edge index was found to be 0.544 . Analysing the data, the most important factor affecting the index value was the road usage that constituted the city boundary, 
and provides access to the industrial areas in the city wall. Roads accounted for $25 \%$ of the total limit index. Agricultural areas significantly impacted the formation of the edge analysis value of 1954 , with a share of $19.3 \%$. The ratio of agricultural areas in total border index was $28.1 \%$. The $18 \%$ representation of the residential areas in the city wall was decisive in the analysis value. The ratio of residential areas in the total boundary index was $19.1 \%$. On the boundary of the urban area in $1954,7.7 \%$ of the total border index was composed of empty parcels, and $7.5 \%$ of the public areas. Industrial areas were included in the edge index with a share of $4.8 \%$.

Examining the edge analysis data of 1971, the result of the edge index was 0.576 . When analyzed, the most outstanding factor affecting the index value was the agricultural areas accounting for $32.8 \%$ of the total border index. Following this, roads providing the connection between the uses, were in the total edge index with $20.6 \%$, and the housing areas with $18.1 \%$. Open green spaces accounted for $11.1 \%$ of the total limit. The ratio of public spaces was $5.4 \%$, and the proportion of industrial spaces was $1 \%$. When the 1971 urban area boundary-uses are compared with the previous data year, a decrease in the ratio of industrial areas is present; an indication of the industrial areas remaining within the city because of the growth of the city. Hence, the decrease in the proportion of public spaces at the border can be interpreted by the development of new types of urban land-use around the public spaces and the remaining public spaces within the border. Upon evauatuation, it is possible to state that the city expanded in line with the needs of housing-use in the direction of agricultural areas, and new road connections between uses affected the border.

Accrding to the edge analysis data of 1994, the result of the edge index was 0.561 and analyzing it, the most essential factor affecting the index value was the housing areas. By far, the residential areas constituted $39.2 \%$ of the total border index, reflecting a rapid growth of residential area-use prior to the $20.9 \%$ of the total edge index composing of agricultural areas and $16.6 \%$ of roads. Open green spaces accounted for $7.5 \%$, and public areas for $6.8 \%$ of the edge index. The share of industrial areas in the index was $1.4 \%$. In the 1994 urban area boundary, while a decline was evident in the ratio of agricultural areas at the total border, there is a direct correlation between residential areas, and road use.

Evaluating the edge analysis data for 2004, the result of the edge index was 0.580 . Analyzing the data, the most crucial factor affecting the index value was the agricultural areas. The growth of the city in the direction of agricultural areas resulted in agricultural areas to be located at the border, accounting for $35.7 \%$ of the total index. Other area-uses constituting the edge index value were roads with a rate of $18.8 \%$, and residential areas with a rate of $14.7 \%$. Additionally, the impact of new roads connecting the new urban land-uses was outstanding. In this data year, the share of open green spaces in the index decreased compared to empty parcels which had a share of $11.2 \%$ in the edge index. The rate of public spaces was $6.0 \%$, and the proportion of industrial spaces; $3.1 \%$. In order to make a general evaluation regarding the edge analysis values between 1954-2004, the use of border areas were shaped as agricultural areas, residential areas and roads. It is clear that the boundary area-uses, surrounding the city, mostly oppose each other. The use of discordant areas at the border can be evaluated in two ways. Unsuitable uses within the border will lead to an ecologically negative result if they suppress natural areas outside the border. However, if the uses close to the natural areas within the border are connected with the natural areas outside the border, it may positively affect the ecological structure of the city.

\section{References}

American Planning Association. (2003). Land Based Classification Standarts. https://planning-org-uploaded-media. s3.amazonaws.com/document/LBCS.pdf

Atalay, B. (1967). Türk Halıcılığı ve Uşak Halıları. Türkiye İş Bankası Kültür Yayınları, İstanbul.

Bairoch, P. (1988). Cities and economic development: From the dawn of history to the present. Mansell, London.

Bennett, A. F. (2003). Linkages in the landscape: The role of corridors and connectivity in wildlife conservation. IUCN, The Word Conservation Union, Cambridge. https://portals.iucn. org/library/efiles/documents/FR-021.pdf

Çakmak, B. (2008). XX. Yüzyıl Basında Usak’ta Kurulan İp Fabrikaları. Uşak Üniversitesi Sosyal Bilimler Dergisi, 1(2), 41-58. https://dergipark.org.tr/en/pub/usaksosbil/issue $/ 21654 / 232805$

Cook, E. A. (2000). Ecological networks in urban landscapes [PhD Dissertation]. Wageningen University, The Netherlands.

Deniz, B. (2005). Use of landscape structure indices in assessing urban land use transformation and their contribution in urban planning practices: Case of the city of Aydin. Ege University.

Dramstad, W. E., Olsan, J. D., \& Forman, R. T. T. (1996). Landscape ecology principles in landscape architecture and land use planning. Island Pres, Washington.

Esbah, H. (2001). Using landscape structure indices to understand the possible impacts of landscape change: Case of the City of Phoenix [Arizona Dissertation]. Arizona, State University, A.Z.

Forman, R. T. T. (1995). Land mosaics: The ecology of landscape and regions. Cambridge University Press. https://doi.org/10.1017/9781107050327

Forman, R. T. T., \& Godron, M. (1986). Landscape ecology. John Wiley and Sons.

General Directorate of Rural Services. (1997). Land report of Usak. Ministry of Agriculture and Rural Affairs, Ankara.

Gulinck, H., Walpot, O., \& Janssens, P. (1993). Landscape structural analysis of Central Belgium using SPOT data. Landscape Ecology and GIS, 75(86), 129-139.

https://lirias.kuleuven.be/1565362?limo=0

Ji, W., Ma, J., Twibell, R. W., \& Underhill, K. (2006). Characterizing urban sprawl using multi-stage remote sensing images and landscape metrics, computers. Environment and Urban Systems, 30(6), 861-879.

https://doi.org/10.1016/j.compenvurbsys.2005.09.002

Jim, C. Y., \& Chen, S. S. (2003). Comprehensive greenspace planning based on landscape ecology principles in compact 
Najing city, China. Landscape and Urban Planning, 65(3), 95-116. https://doi.org/10.1016/S0169-2046(02)00244-X

Lioubimtseva, E. (2003). An evaluation of Vegetation-1 imagery for broad-scale landscape mapping of Russia: Effects of resolution on landscape pattern. Landscape and Urban Planning, 65(4), 187-200.

https://doi.org/10.1016/S0169-2046(03)00024-0

McGarigal, K., \& Marks B. J. (1995). Fragstats: Spatial pattern analiysis program for quantifing landscape structure. Forest Science Department, Oregon State University Pres. Corvallis. http://www.umass.edu/landeco/pubs/mcgarigal.marks.1995. pdf

Meffe, G. F., \& Carroll, C. R. (1997). Principles of conservation biology ( $2^{\text {nd }}$ ed.). Sinauer Associates, Sunderland, MA. https://www.worldcat.org/title/principles-of-conservationbiology/oclc/807303882

Pax-Lenney, B. T., \& Woodcock, C. E. (1997). The effect of spatial resolution on the ability to monitor the status of agricultural lands. Remote Sensing Environment, 61(2), 210-220. https://doi.org/10.1016/S0034-4257(97)00003-5

Patton, D. R. (1975). A diversity index for quantifying habitat edge. Wildlife Society Bulletin, 396, 171-173.

Prevedello, J. A., Figueiredo, M. S. L., Grelle, C. E. V., \& Vieira, M. V. (2013). Rethinking edge effects: The unaccounted role of geometric constraints. Ecography, 36(3), 287-299. https://doi.org/10.1111/j.1600-0587.2012.07820.x

Sen, H., Çemrek F., \& Özaydın, Ö. (2006). Provincial level determining the socio-economic development in Turkey. Selcuk University Faculty of Economics of Social and Economic Research Journal, 6(11), 155-171.

Shaw, W. W., Haris, L. K., Livingston, M., Charpenter, J. P., \& Wissier, C. (1996). Pima County Habitat Inventory: Phase II (Report to Arizona Game and Fish Department). A.Z.

Small, C., \& Miller R. B. (1999). Monitoring the urban environment from space [Conference presentation]. The International Symposium a Digital Earth, Beijing.
Soule, M. E. (1991). Land use planning and wildlife maintenace guidelines for conserving wildlife in an urban landscape. Journal of the American Planning Association, 57(3), 313-323. https://doi.org/10.1080/01944369108975502

Sounders, D. A., Hobbs, R. J., \& Margules, C. R. (1991). Biological consequences of ecosystem fragmentation: A review. Conservation Biology, 5(1), 18-32.

https://doi.org/10.1111/j.1523-1739.1991.tb00384.x

State Statistics Institute. (2008). Usak İli Nüfusu. https://www.nufusu.com/il/usak-nufusu

Stevens, S. M., \& Husband, T. P. (1998). The influence of edge on small mammals: Evidence from Brazilian Atlantic forest fragments. Biological Conservation, 85(1-2), 1-8. https://doi.org/10.1016/S0006-3207(98)00003-2

Tolessa, T., Senbeta, F., \& Kidane, M. (2016). Landscape composition and cofigurtion in the central highlands of Ethiopia. Ecology and Evolution, 6(20), 7409-7421. https://doi.org/10.1002/ece3.2477

Usak Chamber of Commerce and Industry. (2008). Business directory. Usak. https://www.usakticaretrehberi.com/

Usak Meteorology Directorate. (2008). Meteorological data of Usak Province. Usak. https://www.mgm.gov.tr/veridegerlendirme/il-ve-ilceler-istatistik.aspx?m=USAK

Wegner, J. F., \& Merriam, G. (1979). Movements by birds and small mammas between a wood Adjoning farmland habitats. Journal of Applied Ecology, 16(2), 349-357. https://doi.org/10.2307/2402513

$\mathrm{Wu}$, J. (2013). Key concepts and research topics in landscape ecology revisted: 30 years after the Allerton Park workshop. Landscape Ecology, 28, 1-11. https://doi.org/10.1007/s10980-012-9836-y 